\title{
Location Site Selection Preferences of Construction Firms that Offer Second Homes to Foreign Investors: The Case of Trabzon
}

\author{
Ceren Ünlü Öztürk $\odot 1$, Ersin Türk $\odot 2$ \\ ${ }^{1}$ Res. Asst., Faculty of Architecture, Karadeniz Technical University, Trabzon, Turkey. (Principal contact for editorial \\ correspondence.), Email: cerenunluozturk@gmail.com \\ ${ }^{2}$ Assoc. Prof. Dr., Faculty of Architecture, Karadeniz Technical University, Trabzon, Turkey. Email: ersinturk@ktu.edu.tr
}

\begin{abstract}
Purpose

Being necessarily proactive, spatial plans should consider national and global developments. In Turkey, after legislative amendments of the 2000s, legal obstacles for foreign investment in houseownership were eradicated, raising a significant demand for second homes. If the current planning process does not turn this demand into an opportunity, it will probably be one of its main threatening factors. This study aims to uncover the criteria affecting the locational choices of construction companies for their project area in supplying second homes for those investors, and rank them according to their importance.

Design/Methodology/Approach

A three-stage AHP was utilized. First, the objectives, criteria and sub-criteria affecting the locational choices of construction companies were determined and a hierarchical structure was set. Secondly, pairwise comparisons were made with the company officials. Thirdly, the relative and general weights of the criteria and sub-criteria were calculated and locational preferences for the project area were uncovered. The city of Trabzon, where the second home supply for the citizens of the countries in Arabian Peninsula increased after 2012, was chosen as the case.

Findings

It is concluded that the development plan decisions are very effective in the locational selection of the project areas. The most important criteria in the selection process are found to be the nearby plan decisions, high unit $/ \mathrm{m}^{2}$ sale price of flats, and plan decisions on the parcel, in turn. Moreover, the ones for the sub-criteria were found to be having nearby a CBD plan decision, development order, and having a nearby recreational area plan decision, in turn.

\section{Research Limitations/Implications}

Although there are many such construction companies, only two company officials volunteered to participate, yet the study still provides a basis for future work and an awareness for international dynamics of the city.

\section{Originality/Value}

The criteria affecting the locational choices of construction companies for their project area in supplying second homes for foreign investors were revealed and ranked. Pairwise comparisons in AHP were made simultaneously with the participants using a videoconference application, considering the risk of Covid-19. The study contributes to housing supply literature and guide spatial plans by introducing locational preferences of the firms.
\end{abstract}

Keywords: AHP, housing supply to foreigners, location site selection, second home 


\section{INTRODUCTION}

Ersoy (2017) states that spatial planning should be a future-oriented design, that it should be done in order to achieve certain objectives/goals and that it should create a systematic action sequence. It is expected that spatial plans prepared with 15-20-year objectives predict and direct the housing supply and demand within the market mechanism in order to have the right information infrastructure. Otherwise, the process which is left to free market conditions may cause unplanned and unforeseen situations to arise in the designs, objectives/goals and action sequences of the current spatial plans. These unplanned and unforeseen developments may result in changes that will cause the plan become obsolete, or the sector produces its own solutions within the market mechanism. In both cases, this is a failure of the planning and the plan in a sense, as an urban development has emerged which the plan did not foresee.

Homes that foreigners buy outside of their own country are called second homes. Second home is defined in the Glossary of Urban Science Terms as "a unit of residence that people use in their vacations or short-term trips apart from their homes where they live permanently" (Keleş, 2009). The main characteristics of the second homes that make them different from the first houses where households live permanently are said to be: The duration of use, frequency of use, their functions (suitability for recreational purposes such as entertainment, resting, having a holiday, etc.) (Karaaslan and Yalçıner Ercoşkun, 2005) and their location. In general, second homes are located on the coasts where the tourism sector is developing and in regions with high natural qualities (Coppock, 1977; Huang and Yi, 2011; Kaltenborn and Clout, 1998; Nepal and Jamal, 2011; Overvag and Berg, 2011) and are located close to urban settlements (Bakırcl, 2007; Gündüz, 2003; Mizan, 1994).

There have been two important turning points in the legal amendments about foreigners' acquisition of real estates in Turkey. The first of these is the removal of the article which prohibited foreigners from acquiring real estates in villages from the Village Law in 2004. The second is the abolition of the principle of reciprocity in 2012, which had been in the Land Registry Law since the foundation of the In terms of foreigners' acquisition of immovable properties, the principle of reciprocity means if Turkish citizens have the right to acquire immovable properties in one country, the citizens of that country also have the right to acquire immovable properties in Turkey. In 2012, this principle was abolished and the authority to determine which country citizens could buy houses in Turkey was given to the Council of Ministers. From that year on, the citizen of countries that were not granted the right to acquire immovable properties in Turkey were granted the right to acquire immovable properties in Turkey. With the granting of this right, the citizens of the countries in the Arabian Peninsula started to buy high quantities of houses in Turkey. Table 1 shows the number of houses purchased by foreigners between 2015 and 2020 by country. While the total number of 
1 TURKSTAT explains that the difference in the total number of houses purchased by foreigners in Tables 1 and 2 is due to the fact that different nationalities can buy the same house.
Location Site Selection Preferences of Construction Firms that Offer Second Homes to Foreign Investors: The Case of Trabzon

second homes purchased by foreigners between 2015 and 2017 was around 20,000, it doubled in 2018, and reached approximately 41,000 in 2020 despite the pandemic. Iraqi citizens are those who bought the most second homes; in general, the citizens of the Arabian Peninsula demanded second homes; and the citizens of Germany and England from among European countries were among the top ten in the ranking. It is estimated that some of the foreigners who bought second homes in Turkey bought second homes in Turkey due to the security concerns in their own countries.

Table 1. Number of houses purchased by foreigners between 2015 and 2020 by country (Turkish Statistical Institute (TURKSTAT), 2021)

\begin{tabular}{|l|l|l|l|l|l|}
\hline \multicolumn{2}{|c|}{2015} & \multicolumn{2}{c|}{2016} & \multicolumn{2}{c|}{2017} \\
\hline Iraq & 4228 & Iraq & 3036 & Iraq & 3805 \\
\hline SaudiArabia & 2704 & SaudiArabia & 1886 & SaudiArabia & 3345 \\
\hline Kuwait & 2130 & Kuwait & 1744 & Kuwait & 1691 \\
\hline Russia & 2036 & Russia & 1224 & Russia & 1331 \\
\hline Un.Kingdom & 1054 & Afghanistan & 1205 & Afghanistan & 1078 \\
\hline Germany & 869 & Un.Kingdom & 827 & Azerbaijan & 942 \\
\hline Azerbaijan & 815 & Germany & 714 & Un.Kingdom & 794 \\
\hline Iran & 744 & Iran & 664 & Iran & 792 \\
\hline Afghanistan & 656 & Azerbaijan & 610 & Germany & 772 \\
\hline Ukraine & 608 & Ukraine & 484 & Egypt & 587 \\
\hline Other & 7147 & Other & 5997 & Other & 7291 \\
\hline Total1 & 22991 & Total ${ }^{1}$ & 18391 & Total 1 & 22428 \\
\hline \multicolumn{5}{|l|}{2018} & \multicolumn{4}{|l|}{2020} \\
\hline Iraq & 8205 & Iraq & 7596 & Iran & 7189 \\
\hline Iran & 3652 & Iran & 5423 & Iraq & 6674 \\
\hline SaudiArabia & 2718 & Russia & 2893 & Russia & 3078 \\
\hline Russia & 2297 & SaudiArabia & 2208 & Afghanistan & 1929 \\
\hline Kuwait & 2199 & Afghanistan & 2191 & Azerbaijan & 1279 \\
\hline Afghanistan & 2084 & Kuwait & 1903 & Germany & 1265 \\
\hline Germany & 1866 & Germany & 1723 & Kuwait & 1231 \\
\hline Jordan & 1362 & Jordan & 1596 & Yemen & 1181 \\
\hline Azerbaijan & 1250 & Yemen & 1564 & Kazakhstan & 1171 \\
\hline Un.Kingdom & 1237 & Un.Kingdom & 1353 & Un.Kingdom & 1126 \\
\hline Other & 13174 & Other & 17517 & Other & 15175 \\
\hline Total1 & 40044 & Total ${ }^{1}$ & 45967 & Total 1 & 41298 \\
\hline
\end{tabular}

Before 2012, rather the citizens of European Union member states bought individual sections in the Aegean, Mediterranean and Marmara coasts in Turkey (Görer Tamer, Erdoğanaras, Yüksek and Güzey, 2010). A large part of the total number of houses sold to foreigners in Turkey between 2013 and 2020 was in Istanbul and Antalya provinces (Table 2). Antalya is the province where most houses were bought between 2019 and 2014, and İstanbul is the province where most houses were bought between 2019 and 2020. Before 2012, Turkey was rather preferred by the EU citizens, and with the legal amendments some previously undemanded provinces started to be preferred. Of these, Yalova, Trabzon and Sakarya provinces have become prominent. Due to the pandemic (Covid-19) in 2020, the house demand of the citizens of the countries in the Arabian Peninsula in these provinces was interrupted; however, it is anticipated that this demand will continue in the future. Estimating, 
directing and turning the investments into opportunities in order to meet this demand is a planning problem; for, if the current plans do not turn this into an opportunity, there is a risk that this will turn into an element that will threaten the current plans.

Table 2. Number of houses bought by foreigners between 2013 and 2020 by provinces (TURKSTAT, 2021)

\begin{tabular}{|l|l|l|l|l|l|l|l|}
\hline \multicolumn{2}{|c|}{2013} & \multicolumn{2}{c|}{2014} & \multicolumn{2}{c|}{2015} & \multicolumn{2}{c|}{2016} \\
\hline Antalya & 5548 & Antalya & 6542 & İstanbul & 7493 & İstanbul & 5811 \\
\hline İstanbul & 2447 & İstanbul & 5580 & Antalya & 6072 & Antalya & 4352 \\
\hline Aydın & 1112 & Aydın & 1191 & Bursa & 1501 & Bursa & 1318 \\
\hline Muğla & 1053 & Muğla & 1051 & Yalova & 1425 & Aydın & 871 \\
\hline Mersin & 545 & Bursa & 954 & Aydın & 1107 & Yalova & 822 \\
\hline Bursa & 375 & Mersin & 783 & Sakarya & 833 & Trabzon & 810 \\
\hline Yalova & 284 & Yalova & 765 & Muğla & 830 & Sakarya & 657 \\
\hline İzmir & 194 & Sakarya & 512 & Trabzon & 778 & Muğla & 632 \\
\hline Ankara & 175 & Ankara & 369 & Mersin & 717 & Ankara & 623 \\
\hline Sakarya & 103 & Trabzon & 225 & Ankara & 599 & Mersin & 580 \\
\hline Other & 345 & Other & 987 & Other & 1475 & Other & 1713 \\
\hline Total & 12181 & Total & 18959 & Total & 22830 & Total & 18189 \\
\hline \multicolumn{2}{|c|}{2017} & \multicolumn{2}{|c|}{2019} & & & 2020 \\
\hline İstanbul & 8182 & İstanbul & 14270 & İstanbul & 20857 & İstanbul & 19175 \\
\hline Antalya & 4707 & Antalya & 7938 & Antalya & 8951 & Antalya & 7735 \\
\hline Bursa & 1474 & Bursa & 2720 & Ankara & 2539 & Ankara & 2746 \\
\hline Yalova & 1079 & Ankara & 2133 & Bursa & 2213 & Bursa & 1340 \\
\hline Trabzon & 978 & Yalova & 2063 & Yalova & 1696 & Yalova & 1321 \\
\hline Aydın & 826 & Sakarya & 1366 & Sakarya & 1247 & Mersin & 1313 \\
\hline Ankara & 817 & Trabzon & 1344 & Muğla & 957 & İzmir & 908 \\
\hline Sakarya & 770 & Aydın & 1070 & Trabzon & 935 & Samsun & 880 \\
\hline Muğla & 634 & Mersin & 1022 & Samsun & 885 & Sakarya & 864 \\
\hline Mersin & 600 & Samsun & 956 & Aydın & 837 & Muğla & 745 \\
\hline Other & 2167 & Other & 4781 & Other & 4366 & Other & 3785 \\
\hline Total & 22234 & Total & 39663 & Total & 45483 & Total & 40812 \\
\hline
\end{tabular}

In this study, AHP from Multi-Criteria Decision-Making Support Systems (MCDMSS) was employed to determine the building site preference priorities of construction companies that build and sell second homes for Arab Investors.

In the first stage, by using the literature and the characteristics of the field of work, the objectives, criteria and sub-criteria affecting the location preferences of the two construction companies that supply houses to the citizens of the countries in the Arabian Peninsula were determined, and a hierarchical structure was created in accordance with the AHP technique. The first level of this hierarchical structure contains the goals, the second level contains the objectives, the third level contains the criteria and the fourth level contains the sub-criteria. In the second stage, pairwise comparisons were made in accordance with the AHP. These pairwise comparisons were made by one official from each of the two construction companies under the supervision of the authors of the present study. In the third stage, the relative and general weights of the criteria and sub-criteria were calculated and the project area location site selection preferences were revealed. 


\section{LITERATURE REVIEW}

In the literature, there are studies that deal with the issue of second house acquisition by foreigners from different perspectives. These studies mostly focus on foreigners who want second houses, on the characteristics of the demands, and on the effects of the second home acquisition on the area. A limited number of studies have been conducted on the relationship between second home location selection of foreigners and spatial planning.

Studies focusing on the demand for second house acquisition by foreigners generally focused on the characteristics of foreigners and the reasons for acquiring a second house and established their relationship with migration (Breuer, 2005; Farstad and Rye, 2013; Müller, 2002; Müller and Roger, 2011; Norris and Winston, 2010). It is possible to categorize studies on the effects of second house acquisition as economic, social and physical effects. Studies investigating the economic effects mostly examined the changes in house prices and the contribution of foreigners to the local economy (Avcl, Avcı and Şahin, 2008; Bohlin, 1982; Guest and Rohde, 2017; Karakaya and Turan, 2006; Paris, 2017; Südaş and Mutluer, 2008; Wokker and Swieringa, 2016). In studies on social impacts, studies were conducted on how foreigners' second house acquisition affects local identity and the relations between local people and foreigners (Casado-Diaz, 2009; Gustafson, 2008; Hall and Müller, 2004; Nudralı, 2007; O'Reilley, 2001; Rye, 2011). Studies examining the physical effects focused on the protection of natural areas, on the change of existing construction, and on the relationship with urban planning (Alipour, Olya, Hassanzadeh and Rezzapouraghdam, 2017; Bakırcl, 2007; Erdoğanaras, Güzey, Görer Tamer and Yüksel, 2005; Görer Tamer et al., 2010; Gündüz, 2003; Mizan, 1994; Rovira Soto and Clave, 2017; Zoğal and Emekli, 2018). In the literature, while there are limited studies on the second house location selection of foreigners (Gauder, Houssard and Orsmond, 2014; Lipkina, 2013), there are more studies on the location selection of second houses (Burby III, Donelly and Weiss, 2007; Kaltenborn and Clout, 1998; Li and Fan, 2020; Manaugh and El-Geneidy, 2013; Stewart and Stynes, 1995). In addition, studies on second house location selection are more demand-oriented and studies on supply are limited (Gallent and Tewdwr-Jones, 2001).

Studies conducted in Turkey usually focused on the Aegean and Mediterranean Regions, where the citizens of European Union countries acquired second houses (Avcl et al., 2008; Bakırcl, 2007; Erdoğanaras et al., 2005; Görer Tamer, Erdoğanaras, Güzey and Yüksel, 2006; Görer Tamer et al., 2010; Karakaya ve Turan, 2006; Mizan, 1994; Nudrall, 2007; Südaş ve Mutluer, 2008; Yirik ve Baltacl; 2016). These studies mostly focused on the immigration of foreign pensioners and its effects. Studies on the citizens of Arab countries who have acquired the right to house acquisition in our country after 2012 and the cities where they have acquired second houses are limited (Alkan Gökler, 2021; Ünlü Öztürk and Yllmaz Bayram, 2021). This study aims to determine the criteria for the 
project area location selection of the construction companies that supply second houses to foreigners and to rank them according to their importance. It is hoped that it will fill an important gap in the literature and will contribute to the planning practice.

\section{RESEARCH METHOD}

\section{Field of Work}

In this study, the urban region of Trabzon was chosen as the sample field of work (Figure 1). The urban region includes Ortahisar-the central district of Trabzon-, the district of Yomra in the east and the district of Akçaabat in the west. The urban region of Trabzon has developed in a linear macro form parallel to the coast and this development still continues.

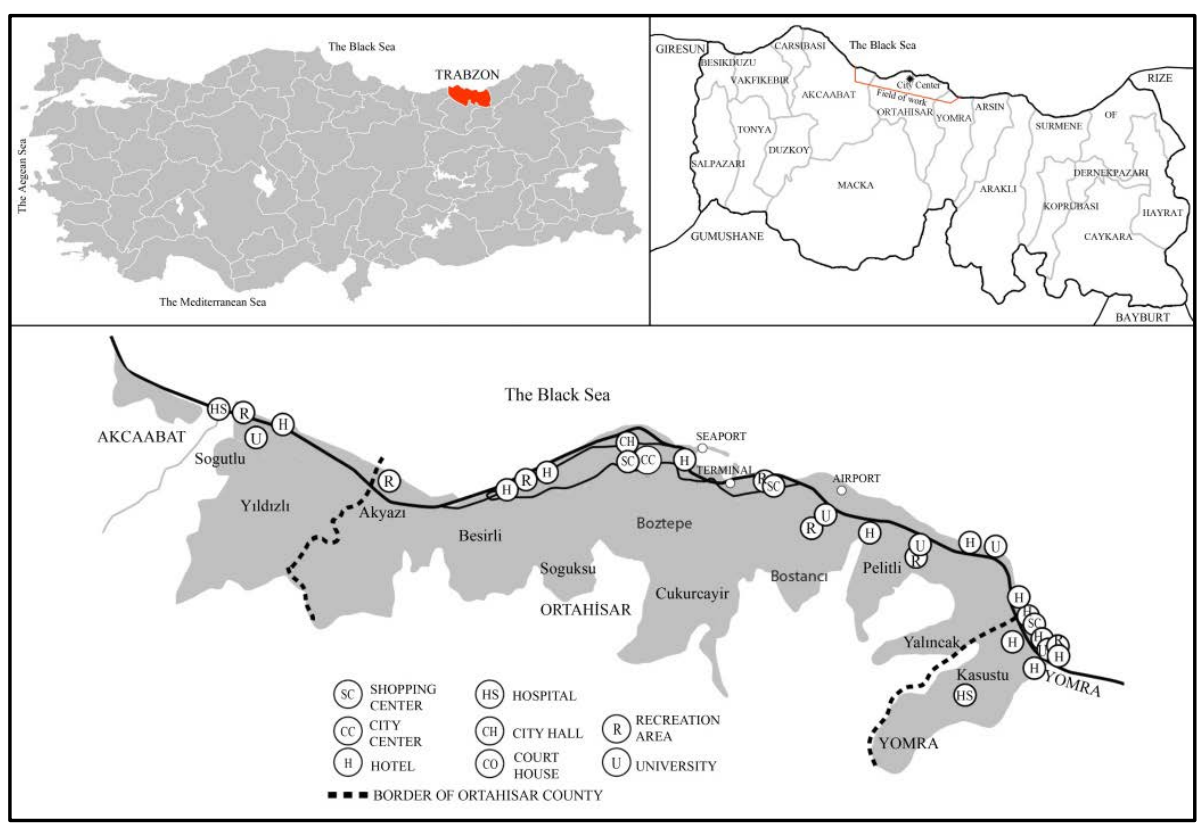

Many construction companies have been building second homes for Arab investors in recent years in the urban region of Trabzon, and Arab investors buy houses. In Trabzon, during the years when the acquisition of houses of the citizens of the countries in Arabian Peninsula increased, the promotions and advertisements of house projects were made in Arabic. In terms of second home investments, the eastern border neighborhood of Ortahisar district, Yalıncak, and Kaşüstü neighborhood of Yomra district stand out (Ünlü, 2018).

\section{Method}

This study employed the AHP technique, one of the Multi-Criteria Decision-Making (MCDM) methods. MCDM is a decision-making support system that offers systematic methods in the analysis of complex decision-making problems. The stages of this analytical system consist of the following respectively: dividing the decision-making problem into small and understandable pieces, analyzing each piece, and attaining a
Figure 1. The location of the urban region of Trabzon - the field of work - within the country and the province. 
result by combining the pieces within a certain logic (Malczewski, 1999). The MCDM techniques allow decision-makers to make an analytical decision in the evaluation, selection and ranking of alternatives (Voogd, 1983). MCDM techniques and Geographic Information Systems (GIS) were integrated with each other, and since the 1980s, this integrated system has been widely used in the distribution of environmental and natural resources, transportation, urban and regional planning, waste management, hydrology, and soultion of the problems in agriculture and forestry (Malczewski, 2006). The MCDM techniques are divided into two groups as Multi-Attribute Decision-Making (MADM) and Multi-Objective Decision-Making (MODM) techniques.

MADM is a decision-making support system in which many different criteria are used together for a single purpose (Carver, 1991; Voogd, 1983). Using different criteria together is one of the most important advantages of the technique. The MADM techniques are widely used in the preparation of a land suitability map for any type(s) of land use, or location selection of any facility (Dai, Lee and Zhang, 2001; Pereira and Duckstein, 1993), and in ordering and selecting a limited number of predetermined alternatives in planning (Carver, 1991; Türk, 2018; Zucca, Sharifi and Fabbri, 2007). AHP, Analytical Network Process, Vikor, Topsis, Mora, Electre, Promethee are some of the MADM techniques. The MODM techniques are operational/mathematical programming used to determine the optimum alternative when the alternatives are infinite and unlimited (Çelik and Türk, 2011; Silva, Alçada-Almeida and Dias, 2017; Türk and Çelik, 2013; Türk and Zwick, 2019).

Developed by Saaty (1980), AHP is a flexible, useful, packaged software and is widely used in spatial planning problems (Banai-Kashani, 1989; Carver, 1991; Türk, 2018). Many criteria are effective in the project area location selection of construction companies that supply second houses to foreign investors. Most of these criteria do not have a measurement unit, and the measurement units of the criteria that have measurement units are not comparable with each other. AHP was used in this study as it allows to calculate the relative and general weight of the criteria by making a pairwise comparison of criteria that do not have a unit of measurement and have different units of measurement. Another advantage of AHP is that it offers an analytical and hierarchical approach to breaking down very complex decision problems into parts.

The AHP includes three principles and stages as decomposition, pairwise comparative judgment, and synthesis of priorities (Saaty, 1980; Malczewski, 1999). The first stage in AHP is to divide the decision-making problem into hierarchy. In general, the hierarchical structure is as follows: goals, objectives, criteria/attributes, sub-criteria and alternatives. Depending on the purpose of the study, the number of levels and order in the hierarchy may change. Because the purpose of this study is to rank the criteria and sub-criteria in order of importance, alternatives are not included. 
The second stage is the pairwise comparisons of decision elements. Pairwise comparisons in the AHP are the main measure. In the pairwise comparison matrix, each criterion is compared with other criteria according to its component one level higher. When making comparisons according to the importance levels in Table 3, if the criterion in the row of the comparison matrix is more important than the criterion in the column, it takes a value between 1 and 9. Conversely, when the criterion in the column is more important than the criteria in the row, it takes a value between $1 / 2$ and $1 / 9$ (Table 3 ). As a result of the pairwise comparisons, the eigenvector corresponding to the largest eigenvalue of the matrix expresses the relative priorities of the criteria. Thus, a weight vector reflecting the relative importance of various criteria is obtained.

Table 3. Pairwise comparison scale (Saaty, 1980)

\begin{tabular}{|l|l|l|}
\hline $\begin{array}{l}\text { Level of } \\
\text { importance }\end{array}$ & Interpretation & Explanation \\
\hline 1 & Equal importance & $\begin{array}{l}\text { Two activities contribute equally to the } \\
\text { objective }\end{array}$ \\
\hline 3 & $\begin{array}{l}\text { Moderate } \\
\text { importance of one } \\
\text { over another }\end{array}$ & $\begin{array}{l}\text { Experience and judgment moderately favor } \\
\text { one activity over another. }\end{array}$ \\
\hline 5 & $\begin{array}{l}\text { Essential or strong } \\
\text { importance }\end{array}$ & $\begin{array}{l}\text { Experience and judgment strongly favor one } \\
\text { activity over another }\end{array}$ \\
\hline 7 & $\begin{array}{l}\text { Very strong } \\
\text { importance }\end{array}$ & $\begin{array}{l}\text { An activity is strongly favored and its } \\
\text { dominance is shown in practice }\end{array}$ \\
\hline 9 & $\begin{array}{l}\text { Extreme } \\
\text { importance }\end{array}$ & $\begin{array}{l}\text { The evidence favoring one activity over } \\
\text { another is of the highest possible order of } \\
\text { affirmation }\end{array}$ \\
\hline $2,4,6,8$ & $\begin{array}{l}\text { Intermediate } \\
\text { values }\end{array}$ & $\begin{array}{l}\text { Values between two consecutive judgments } \\
\text { to be used when compromise is needed }\end{array}$ \\
\hline
\end{tabular}

When making pairwise comparisons, the scores given by the decision maker must be compatible with each other. To ensure the consistency of subjective perceptions and the accuracy of relative weights, two coefficients, the Consistency Index $(C I)$ and the Consistency Ratio $(C R)$, are used. To test the compatibility, CR is calculated for each comparison matrix. The consistency ratio is used to express the probability of random generation of matrix decisions (Saaty, 1980). The following formula is used to calculate $\mathrm{CI}$.

\section{$C I=(\lambda \max -n) /(n-1)$}

Here, $C I$ denotes the index of consistency and shows the deviation from consistency. $\lambda \max$ is the biggest eigenvalue of the matrix, and $\mathrm{n}$ is the number of elements (criteria/subcriteria) in the matrix.

The CR is calculated with the following formula:

$C R=C I / R I$

Here, $R I$ represents the random value index (Table 4 ). Table 4 shows the $R I$ values according to different element numbers (n).

Table 4. Random value index (Saaty, 1980)

\begin{tabular}{|c|c|c|c|c|c|c|c|c|c|c|}
\hline n: Random & 1 & 2 & 3 & 4 & 5 & 6 & 7 & 8 & 9 & 10 \\
\cline { 2 - 11 } Value Index & 0 & 0 & 0.52 & 0.89 & 1.11 & 1.25 & 1.35 & 1.40 & 1.45 & 1.49 \\
\hline
\end{tabular}


A CR of 0.1 or less is a reasonable consistency level. Otherwise, a consistency ratio above 0.1 would require revision of significance levels in the matrix due to inconsistent evaluation. That $7 \pm 2$ criteria/subcriteria are at comparable level in each comparison matrix is indicated. If the criteria/sub-criteria are more than 9, it is recommended that they be divided into subgroups (Saaty, 1980).

The third step is the calculation of the overall (combined) weights. The relative weights of the levels that were calculated in the second step are combined to obtain the overall weights. For this, the relative weight of each criterion or sub-criterion must be multiplied by the relative weight of the relevant criterion or sub-criterion and the objective at each level in a hierarchical manner from the bottom to the top. These values show the relative weight of criteria or sub-criteria relative to the overall objective (Saaty, 1980; Malczewski, 1999). In the present study, a Microsoft Excel ${ }^{\odot}$ template was developed to implement the AHP algorithm.

In this study, a three-stage process was used. In the first stage, the AHP hierarchy was established by revealing the criteria that affect the location preferences of companies that supply houses to foreign investors In the second stage, the decision-making elements in the AHP hierarchy were compared pairwise by the construction company officials who supplied housing to foreigners in the city of Trabzon. In the last stage, the general weights of the decision-making elements were calculated, and the effects of the criteria and sub-criteria on place selection preferences were revealed.

\section{The first stage: Creating the AHP hierarchy}

In line with the aim of the study, the goal at the first level of the AHP hierarchy was determined as "the project area location site selection preferences of construction companies that supply houses to Arab investors". The second level contains the objectives, and three objective have been determined by using the literature. These are (1) Consumer demand, (2) Development plan and developed site, and (3) Cost and profit. At the third level, there are criteria under each objective, and at the fourth level, there are sub-criteria under each criterion. Criteria and subcriteria were determined by taking into consideration the relevant literature and the characteristics of the field of work.

Under the objective of consumer demand are the criteria of proximity to natural areas (Prx. to natural areas), view, presence of foreign investors in the region (Prs. foreign investor) and proximity to functions in the city (Prx. func. in the city). Under the criterion of proximity to natural areas are the sub-criteria of proximity to the sea, lake, stream, creek, forest and agricultural areas; Under the view criterion are the sub-criteria of sea view, city view and natural area view; under the criterion of proximity to functions in the city are the sub-criteria of proximity to shopping malls, touristic areas, the city center and the airport (Figure 2). 


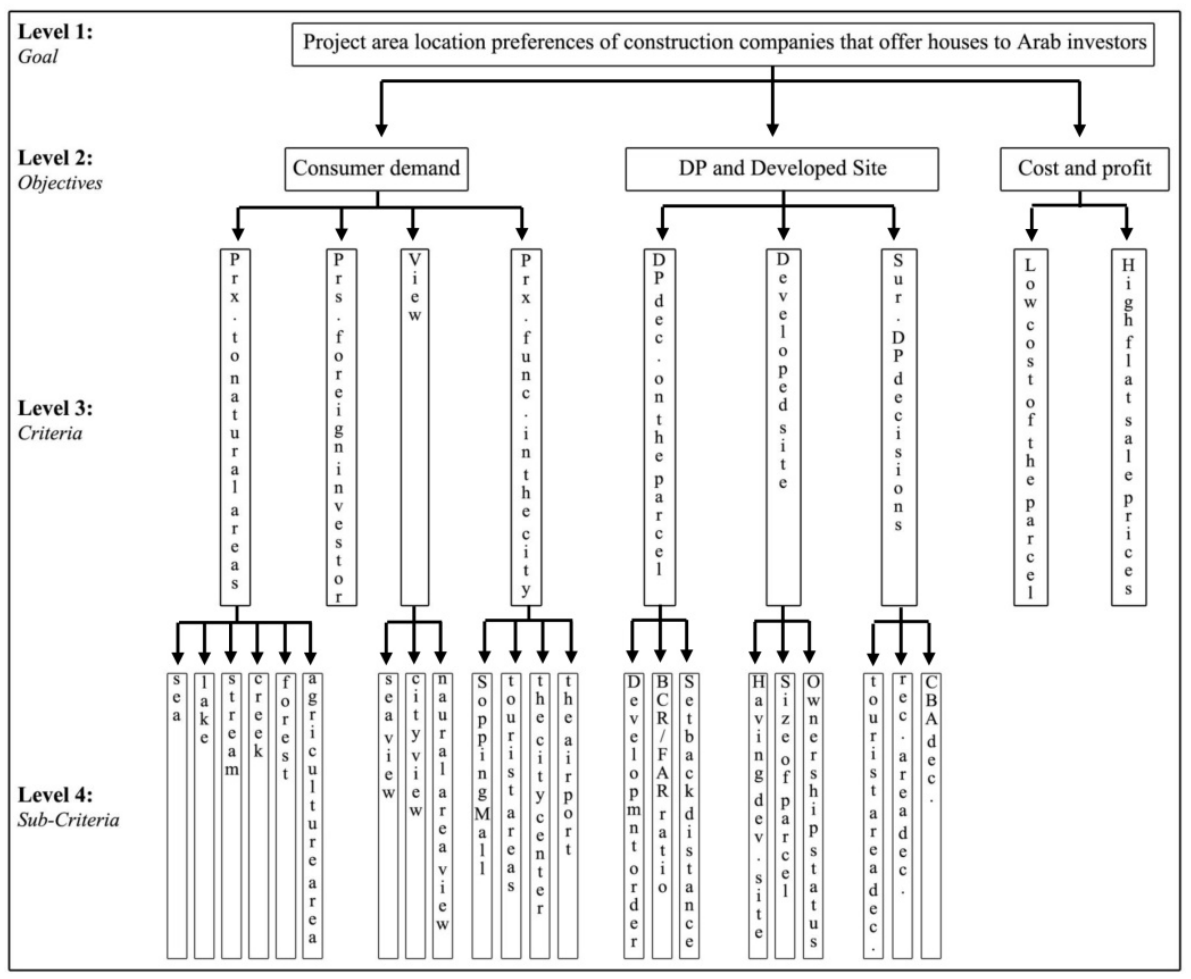

The locations demanded by foreigners for their houses are a guide for construction companies. In general, it is stated that proximity to water (sea, creek, and lake) and green (forest, agricultural areas, natural areas) is of great importance in the second home demands of foreigners (Casado-Diaz, 1999; Ünlü, 2018). In addition, foreigners usually prefer to buy houses in places they have visited and liked as tourists, and their experiences with the city affect them. In this context, proximity to touristic places also emerges as important for the choice of house site (Bakırcl, 2007). In addition to the specified criteria, foreigners mostly prefer to be close to their relatives and acquaintances when buying a house. In this respect, proximity to the places where foreigners that have previously acquired houses in the region live is also effective in the demand (Casado-Diaz, 1999; Hall and Müller, 2004). Another important point is said to be transportation connections. In the acquisition of the second home, the distance between the first and the second home determines the type of transportation and the duration of use (Bakırcl, 2007; Bell and Ward, 2000; Gündüz, 2003; Mizan, 1994). If the distance is short, private vehicles are used; as the distance increases, other means of transportation such as buses, trains and planes are preferred. In the acquisition of the second homes by foreigners, since they travel from one country to another, especially the places that are close to the airport become important. Because the officials that were interviewed stated that foreigners want to be close to areas such as shopping malls and city centers where they can meet their needs in the areas where they buy houses for touristic purposes, proximity to these two functions were also included in the hierarchy as sub-criteria.
Figure 2. The hierarchy of project area site selection and preferences of construction companies that supply houses to Arab investors. 
Under the development plan and developed site (DP and Developed Site) objectives are also the criteria of development plan decisions on the parcel (DP dec. on the parcel), developed site, and development plan decisions in its immediate surroundings about the parcel (Sur. DP Decisions). Under the criterion of development plan decisions on the parcel are the sub-criteria of development order, Building Coverage Ratio (BCR) / Floor Area Ratio (FAR) and set-back distances; under the developed site criterion are sub-criteria of having developed site on the parcel (Having dev. site), size of parcel and ownership status; under the criterion of development plan decisions in its immediate surroundings about the parcel; having a tourism area plan decisions in its immediate surroundings (tourist. area dec.), having a recreational area plan decision in its immediate surroundings (rec. area dec.), and having a central business area plan decision in its immediate surroundings (CBA dec.) were determined as the sub-criteria (Figure 2).

The development order in the current implementation development plan of the real estate to be projected is important in terms of the development rights granted to the real estate. These rights involve the BCR and FAR, which indicates the total construction area, and setback distance. In her study, Ünlü (2018) found that immovable with a FAR decision on the plan are preferred, especially in the implementation plan. On a parcel planned in FAR, because vertical development is permitted by reducing the BCR without changing the FAR, the yard becomes larger, and this allows the yard to be used for such common functions as parking lot, green area, pool, etc. The authorities that were interviewed stated that another reason for preference is that the immediate surroundings of the second homes that the foreigners will use for entertainment and holiday purposes has, with all its functions, a planned tourism area or a central business area or a recreation area. That an immovable has been implemented a a developed site in accordance with Article 18 of the Zoning Law No. 3194 indicates that the necessary public areas have been abandoned from the cadastral parcel to the public areas within the scope of the participation share of readjustment, the immovable will not be abandoned again, and the immovable has reached the stage of obtaining a building license. That an immovable property is owned by one person is an advantage over a multi-ownership in resolving a future dispute after the owner of the immovable has made a contract with the contractor. In this context, ownership status is also important (Çağla, 2007).

Under the cost and profit objective, there are such criteria as low cost of the parcel and high flat unit $/ \mathrm{m}^{2}$ sale prices. With these criteria, the investor makes a cost-profit comparison. While choosing the location of the housing area, the areas with low land costs are preferred primarily (Meyer and Gomez - Ibanez, 1981). Especially after the second half of the 20th century, with the development of transportation technologies, living close to the city center has become less important and low-cost lands in the periphery of cities have started to be preferred. In this context, low land prices are important for the choice of housing area. Another 
important point is the high house unit price $/ \mathrm{m}^{2}$ after the project is prepared (Kocatürk Özcan, 2006).

\section{The second stage: Pairwise comparisons of decision elements}

Pairwise comparisons were made in accordance with the hierarchy created in the first stage. Pairwise comparisons were made by the construction company officials that produce second homes for Arab investors. Between 2012 and 2017, when foreigners' house acquisition was high in Trabzon, the companies that promoted housing projects on the internet and the number of projects they produced were determined (Ünlü, 2018). It was found that $75 \%$ of the housing projects were produced by only 6 companies and $25 \%$ by 31 companies. Then, 6 company representatives were contacted. Of the 6 companies, two agreed to participate in the study. An official from each of the two construction companies, who agreed to participate in the study, made pairwise comparisons, in the form of a group meeting, using a videoconference application. In the videoconference, the group was first informed about the aim of the study, the scoring system and AHP. Then, they made pairwise comparisons. In pairwise comparisons, the scores given by the group in agreement were entered into the comparison matrices simultaneously by one of the authors of the study. Pairwise comparisons were made by considering the related goal, objective and criterion at the next higher level.

\section{The third stage: Calculation of priority values of decision elements}

In the third step, first the relative weights of the objectives, criteria and sub-criteria, then the general weights of the criteria and sub-criteria were calculated. The relative weight of each criterion was multiplied by the relative weight of the respective objective in the higher hierarchy. Thus, the overall weight of each criterion was calculated. The relative weight of each sub-criterion was multiplied by the relative weights of the corresponding criterion and objective in the upper hierarchies, respectively. Thus, the overall weight of each sub-criterion was calculated.

\section{RESULTS}

The relative weights of objectives in the second level of the hierarchy were calculated by pairwise comparison. Of the objectives, the weight value of consumer demand was found to be 0.105 , of development plan and developed site 0.637 , and of cost/profit 0.258 .

In the next step, the relative weights of the criteria under each objective at the second level were calculated (Table 5). Under the consumer demand objective, the criterion of view; under the development plan and developed site objective, the criterion of development plan decisions in its immediate surroundings about the parcel; and under the cost/profit objective, the criterion of high flat unit $/ \mathrm{m}^{2}$ sale price received the highest relative weights. At the third level, under each criterion, proximity to the 
Location Site Selection Preferences of Construction Firms that Offer Second Homes to Foreign Investors: The Case of Trabzon

sea, sea view, proximity to the city center, development order, ownership status and the having a central business area plan decision in its immediate surroundings are the sub-criteria that received the highest relative weights. These sub-criteria received at least more than half of the total score in each single pairwise comparison.

Table 5. Relative weights of objectives, criteria and sub-criteria

\begin{tabular}{|c|c|c|c|c|c|}
\hline $\begin{array}{l}\text { Objectives } \\
\text { (Obj.) }\end{array}$ & $\begin{array}{l}\text { Obj. } \\
\text { weight }\end{array}$ & $\begin{array}{l}\text { Criteria } \\
\text { (Cri.) }\end{array}$ & $\begin{array}{l}\text { Cri. } \\
\text { weight }\end{array}$ & Sub-criteria & $\begin{array}{l}\text { Sub-cri. } \\
\text { weight }\end{array}$ \\
\hline \multirow{14}{*}{$\begin{array}{l}\text { Consumer } \\
\text { demand }\end{array}$} & \multirow[t]{14}{*}{0.105} & \multirow{6}{*}{$\begin{array}{l}\text { Proximity to } \\
\text { natural areas }\end{array}$} & \multirow[t]{6}{*}{0.046} & Proximity to the sea & 0.584 \\
\hline & & & & Proximity to the lake & 0.099 \\
\hline & & & & Proximity to the stream & 0.099 \\
\hline & & & & Proximity to the creek & 0.081 \\
\hline & & & & Proximity to the forest & 0.081 \\
\hline & & & & Proximity to agricultural areas & 0.056 \\
\hline & & \multirow[t]{3}{*}{ View } & \multirow[t]{3}{*}{0.573} & Sea view & 0.731 \\
\hline & & & & City view & 0.081 \\
\hline & & & & Naural area view & 0.188 \\
\hline & & $\begin{array}{l}\text { Presence of } \\
\text { foreign } \\
\text { investors in the } \\
\text { region }\end{array}$ & 0.110 & & \\
\hline & & \multirow{4}{*}{$\begin{array}{l}\text { Proximity to } \\
\text { the functions } \\
\text { in the city }\end{array}$} & \multirow[t]{4}{*}{0.271} & Proximity to shopping mall & 0.243 \\
\hline & & & & Proximity to tourist areas & 0.049 \\
\hline & & & & Proximity to the city center & 0.607 \\
\hline & & & & Proximity to the airport & 0.101 \\
\hline \multirow{9}{*}{$\begin{array}{l}\text { Developme } \\
\text { nt plan and } \\
\text { developed } \\
\text { site }\end{array}$} & \multirow[t]{9}{*}{0.637} & \multirow{3}{*}{$\begin{array}{l}\text { Development } \\
\text { plan decisions } \\
\text { on the parcel }\end{array}$} & \multirow[t]{3}{*}{0.243} & Development order & 0.818 \\
\hline & & & & BCR/FAR ratios & 0.091 \\
\hline & & & & Set-back distances & 0.091 \\
\hline & & \multirow[t]{3}{*}{ Developed site } & \multirow[t]{3}{*}{0.088} & $\begin{array}{l}\text { Having a developed site on the } \\
\text { parcel }\end{array}$ & 0.055 \\
\hline & & & & Size of parcel & 0.290 \\
\hline & & & & Ownership status & 0.655 \\
\hline & & \multirow{3}{*}{$\begin{array}{l}\text { Development } \\
\text { plan decisions } \\
\text { in its } \\
\text { immediate } \\
\text { surroundings } \\
\text { about the } \\
\text { parcel }\end{array}$} & \multirow[t]{3}{*}{0.669} & $\begin{array}{l}\text { Presence of an immediate } \\
\text { surrounding having a tourist } \\
\text { area planning }\end{array}$ & 0.063 \\
\hline & & & & $\begin{array}{l}\text { Presence of an immediate } \\
\text { surrounding having a } \\
\text { recreation area planning }\end{array}$ & 0.265 \\
\hline & & & & $\begin{array}{l}\text { Presence of an immediate } \\
\text { surrounding having central } \\
\text { business area planning }\end{array}$ & 0.672 \\
\hline \multirow[t]{2}{*}{$\begin{array}{l}\text { Cost and } \\
\text { profit }\end{array}$} & \multirow[t]{2}{*}{0.258} & $\begin{array}{l}\text { Low cost of the } \\
\text { parcel }\end{array}$ & 0.125 & & \\
\hline & & $\begin{array}{l}\text { High flat } \\
\text { unit } / \mathrm{m}^{2} \text { sale } \\
\text { prices }\end{array}$ & 0.875 & & \\
\hline
\end{tabular}

It should be born in mind that the consistency index should be below 0.1 in pairwise comparisons. Since the consistency index was below 0.1 in all pairwise comparisons, there was no need to revise the pairwise comparisons.

In the next stage, the overall weight of each criterion was calculated. These weights were obtained by multiplying the relative weight of each criterion by the relative weight of the objective (Table 6). development plan decisions in its immediate surroundings about the parcel, high flat unit $/ \mathrm{m}^{2}$ sale price and development plan decisions on the parcel have been the criteria with the highest overall weights. 
Table 6. Overall weight ranking of the criteria

\begin{tabular}{|l|l|l|}
\hline Sequence & Criteria & Overall Weight \\
\hline 1 & $\begin{array}{l}\text { Development plan decisions in its } \\
\text { immediate surroundings about the parcel }\end{array}$ & 0.426153 \\
\hline 2 & High flat unit $/ \mathrm{m}^{2}$ sale prices & 0.225750 \\
\hline 3 & Development plan decisions on the parcel & 0.154791 \\
\hline 4 & View & 0.060165 \\
\hline 5 & Developed site & 0.056056 \\
\hline 6 & Low cost of the parcel & 0.032250 \\
\hline 7 & Proximity to the functions in the city & 0.028455 \\
\hline 8 & $\begin{array}{l}\text { Presence of foreign investors in the } \\
\text { region }\end{array}$ & 0.011550 \\
\hline 9 & Proximity to natural areas & 0.004830 \\
\hline
\end{tabular}

In the last stage, the general (global) weight value of each single subcriterion was calculated. The relative weight of a sub-criterion was multiplied by the relative weights of the corresponding criterion and objective in the upper hierarchies respectively, and thus the overall weight of each sub-criterion was calculated. As seen in Table 7, the subcriterion of the 'having a central business area plan decision in its immediate surroundings,' the sub-criterion of 'develoopment order,' and the sub-criterion of the 'having a recreational area plan decision in its immediate surroundings' have the highest general weights. The total weight of these three sub-criteria is equal to 0.525925, which is approximately equal to the total weight of the remaining 19 sub-criteria. In other words, it can be said that these three sub-criteria are determinant in the choice of location of the project area. While the construction company officials were making the pairwise comparisons, they stated that foreigners want to meet their needs from the close environment. The findings of the study support the actual situation; because the construction companies that produce houses for Arab investors in Trabzon mainly prefer locations in Kaşüstü and Yalıncak regions (Ünlü, 2018). In the last 10 years, tourism facilities, shopping malls, functions requiring large area use and commercial areas have been built in the Kaşüstü and Yalıncak regions, and this region continues to develop as a sub-center (Figure 1). The proximity of the region to the city center, airport and sea has increased its attraction. On the other hand, the development order in the implementation development plan provides great flexibility to the construction companies in the projects to be realized and enables them to increase their profits. The construction company officials stated that in the parcels having a FAR planning, reducing the BCR permits vertical construction without changing the total construction area. In this case, they stated, such recreational areas as parks, swimming pools, sports fields etc. can be built on the unbuilt part of the parcel, which increases the attractiveness of the project. Regarding the ownership status, which is at the top of the general weight ranking, it was stated that the parcels owned by one person are preferred because there are difficulties with the joint-owned parcels both during the agreement period and afterwards. 
Location Site Selection Preferences of Construction Firms that Offer Second Homes to Foreign Investors: The Case of Trabzon

Table 7. Overall weight ranking of sub-criteria

\begin{tabular}{|l|l|l|}
\hline Sequence & Sub-criteria & Overall weight \\
\hline 1 & $\begin{array}{l}\text { Having a central business area plan decision in its } \\
\text { immediate surroundings }\end{array}$ & 0.286375 \\
\hline 2 & Development order & 0.126619 \\
\hline 3 & $\begin{array}{l}\text { Having a recreational area plan decision in its } \\
\text { immediate surroundings }\end{array}$ & 0.112931 \\
\hline 4 & Sea view & 0.043981 \\
\hline 5 & Ownership status & 0.036717 \\
\hline 6 & $\begin{array}{l}\text { Having a tourism area plan desicions in its } \\
\text { immediate surroundings }\end{array}$ & 0.026848 \\
\hline 7 & Proximity to the city center & 0.017272 \\
\hline 8 & Size of parcel & 0.016256 \\
\hline 9 & BCR/FAR ratios & 0.014084 \\
\hline 10 & Set-back distances & 0.014084 \\
\hline 11 & Naural area view & 0.011311 \\
\hline 12 & Proximity to shopping mall & 0.006915 \\
\hline 13 & City view & 0.004873 \\
\hline 14 & Having a developed site on the parcel & 0.003083 \\
\hline 15 & Proximity to the airport & 0.002874 \\
\hline 16 & Proximity to the sea & 0.002821 \\
\hline 17 & Proximity to tourist areas & 0.001394 \\
\hline 18 & Proximity to the lake & 0.000478 \\
\hline 19 & Proximity to the stream & 0.000478 \\
\hline 20 & Proximity to the creek & 0.000391 \\
\hline 21 & Proximity to the forest & 0.000391 \\
\hline 22 & Proximity to agricultural areas & 0.000270 \\
\hline
\end{tabular}

The control mechanism of the administrations on the housing area location selection of the construction companies is the spatial plan. This study has shown that all the criteria and sub-criteria that affect the location selection of the construction companies that produce houses for Arab investors are directly or indirectly related to the spatial plans. It would be useful for city planners who are experts on spatial planning and politicians who are responsible for planning to make planning decisions by being aware of this fact.

\section{DISCUSION AND CONCLUSIONS}

Before 2012, mostly the citizens of European Union member countries bought second homes on the Aegean, Mediterranean and Marmara coasts. In 2012, the principle of reciprocity was abolished by the Council of Ministers, and therefore citizens of those countries that did not have the right to buy houses in Turkey were granted the right to buy houses. After this change, the citizens of the countries in the Arabian Peninsula began to buy large quantities of houses in Turkey. With this development, Arab investors bought many second homes in some cities such as Yalova, Trabzon and Sakarya. In these cities that are experiencing a new process, it is important to identify the demand and to direct this demand in spatial plans. Otherwise, the process that is left to free market conditions may cause unplanned and unforeseen spatial developments in the targets/purposes and action sequences of the current spatial plans.

The aim of this study is to determine the criteria and sub-criteria affecting the location preferences of construction companies that offer second 
homes to the citizens of the countries in the Arabian Peninsula and to uncover their priorities. The works within this scope that shape the spatial plans will contribute to the awareness of the international dynamics of the city and the correct evaluation of these opportunities during the preparation of the plan.

The study unveiled the targets, criteria and sub-criteria affecting the location preferences of the companies that offer houses to foreigners and determined the priorities through weighing them by the construction company representatives. In the location preferences of the construction companies, the study found the following sub-criteria as determinants: development plan decisions in the immediate surroundings, high flat unit $/ \mathrm{m}^{2}$ sale price and the criteria for implementation development plan decisions for the parcel; presence of an immediate surrounding having central business area planning, development order, and presence of an immediate surrounding having a recreation area planning. This indicates that spatial planning decisions are important on the location preferences of companies. The findings of this study have shown that the development plan decisions are the main determining factor in the project area location selection of the construction companies. For this reason, while the development plans are being prepared, it is necessary to take into consideration the second house demand of the citizens of the Arabian Peninsula and the weights of the criteria in the project area location selection of the construction companies that meet this demand. Otherwise, the construction companies will continue to produce second houses for the citizens of the Arabian Peninsula in the areas with central business and recreation areas in the immediate vicinity, even if the current development plans do not foresee. On the other hand, the unplanned second house ownership of the citizens of Arabian Peninsula countries in the city may cause social and spatial problems, especially in the areas that are close to these second houses and in the city. It is necessary to produce plan decisions to reduce or eliminate these problems.

This study employed AHP from MCDMSS techniques. AHP is widely used in choosing and ranking among alternatives in very complex and multicriteria spatial problems. For it has flexible, useful and package programs. In this study, AHP was used in ranking the criteria according to their importance by calculating the relative and general weights of the criteria and sub-criteria. Pairwise comparisons in the AHP were made by videoconferencing, taking into account the risk of Covid-19. Participants made the pairwise comparisons under the control of the authors as a group and simultaneously through videoconference very easily, in a short time, and without any problems. Within this context, preferring videoconferencing instead of face-to-face meetings reduces the risks of Covid-19 epidemic and provides great convenience in conducting the study. 
Location Site Selection Preferences of Construction Firms that Offer Second Homes to Foreign Investors: The Case of Trabzon

Determining and ranking the location selection criteria of Arab investors who buy or want to buy houses with the methodology used in this study is also important for planning studies.

\section{CONFLICT OF INTEREST}

No conflict of interest was declared by the authors.

\section{FINANCIAL DISCLOSURE}

The authors declared that this study has received no financial support.

\section{ETHICS COMMITTEE APPROVAL}

Ethics committee approval was not required for this article.

\section{LEGAL PUBLIC/PRIVATE PERMISSIONS}

In this research, the necessary permissions were obtained from the relevant participants (individuals, institutions, and organizations) during the interviews.

\section{REFERENCES}

Alipour, H., Olya, H.G.T., Hassanzadeh, B. \& Rezapouraghdam, H. (2017). Second home tourism impact and governance: Evidence from the Caspian Sea region of Iran. Ocean \& Coastal Management, 136, 165-176. https://doi.org/10.1016/j.ocecoaman.2016.12.006

Alkan Gökler, L. (2021). Foreign demand and high-rise luxury housing projects in two Turkish cities: Ankara and Trabzon. Land Use Policy, 103, 105-318. https://doi.org/10.1016/j.landusepol.2021.105318

Avcl, M., Avcl, U. \& Şahin, F. (2008). Sosyal ve ekonomik yönüyle Fethiye'ye yabancı göçü. Fethiye Sanayi ve Ticaret Odası.

Bakırcı, S. (2007). Yabancıların ikinci konut talebinin fiziksel çevreye etkisi: Dalyan Örneği (Publication No. 212763) [Master's thesis, Gazi Üniversitesi]. Gazi Üniversitesi Akademik Veri Yönetim Sistemi. https://avesis.gazi.edu.tr/yonetilen-tez/f1d6150a-b54e-4d07-b049513068a69a9c/yabancilarin-ikinci-konut-talebinin-fiziksel-cevreyeetkisi-dalyan-ornegi

Banai-Kashani, R. (1989). A new method for site suitability analysis: The analytic hierarchy process. Environmental Management, 13(6), 685-693. https://doi.org/10.1007/BF01868308

Bell, M. \& Ward, G. (2000). Comparing Temporary Mobility With Permanent Migration. Tourism Geographies, 2(1), 87-107. https://doi.org/10.1080/146166800363466

Bohlin, M. (1982). Second homes in the regional economy: where the cottagers Money go. Geografiskaregionstudier, 14, Kulturgeografiska institutionen.

Breuer, T. (2005). Retirement Migration or Rather Second Home Tourism? German Senior Citizens on the Canary Islands. Journal of the Geographical Society of Berlin, 136, 313-333. 
Burby III, R.J., Donnelly, T.G. \& Weiss, S.F. (2007). Vacation home location: A model for simulating the residential development of rural recreation areas. Regional Studies, 6(4), 421-439. https://doi.org/10.1080/095952 37200185371

Carver, S. J. (1991). Integrating multi-criteria evaluation with geographical information systems. International Journal of Geographical Information Systems, 5(3), 321-339. https://doi.org/10.1080/026937 99108927858

Casado-Diaz M.A. (1999). Socio-Demographic Impacts of Residential Tourism: A Case Study of Torrevieja, Spain. International Journal of Tourism Research, 1, 223-237. https://doi.org/10.1002/(SICI)15221970(199907/08)1:4<223::AID-JTR153>3.0.CO;2-A

Casado-Diaz, M.A. (2009). Social capital in the sun: Bonding and bridging social capital among British retirees. In M. Benson \& K. O'Reilly (Eds.), Life style migration: expectations, aspirations and experience. Ashgate.

Coppock, J.T. (1977). Second homes in perspective. In J.T. Coppock (Ed.), Second Homes: Curse or Blessing? Pergamon Press.

Çağla, H. (2007). Kentsel Dönüşüm Çalışmalarının Mülkiyet Kullanımına Olan Etkisi Üzerine Bir Araştırma ve Konya Örneği (Publication No. 212326) [Master's thesis, Selçuk Üniversitesi]. YÖK Tez Merkezi.

Çelik, H. M. \& Türk, E. (2011). Determination of optimum environmental conservation: Using multicriteria decision-making techniques. European Planning Studies, 19(3), 479-499. https://doi.org/10.1080/0965 4313.2011.548369

Dai, F.C., Lee, C.F. \& Zhang, X.H. (2001). GIS-based geo-environmental evaluation for urban land-use planning: a case study. Engineering Geology, 61(4), 257-271. https://doi.org/10.1016/S00137952(01)00028-X

Erdoğanaras, F., Güzey, Ö., Görer Tamer, N., \& Yüksel, Ü., (2005). Yabancıların Mülk Edinmesi ve Yabancı Orta Yaş Üzeri Emekli Göçünün Kıyı Yerleşmelerine Etkisi: Türkiye Örneği. Planlamada Yeni Politika ve Stratejiler (8 Kasım Dünya SSehircilik Günü 29. Kolokyumu Bildiriler Kitabı) (pp. 119-132). TMMOB Şehir Plancıları Odası.

Ersoy, E. (2017). Planlama kuramları. In S.S. Özdemir. Ö.B.Ö. Sarı \& N. Uzun, N. (Eds.), Kent Planlama (pp. 27-61). İmge Kitapevi.

Farstad, M. \& Rye, J.F. (2013). Second Home Owners, Locals and Their Perspectives on Rural Development. Journal of Rural Studies, 30, 41-51. https://doi.org/10.1016/j.jrurstud.2012.11.007

Gallent, N. \& Tewdwr-Jones, M. (2001). Second homes and the UK planning system. Planning Practice \& Research, 16(1), 59-69. https://doi.org/10.1080/02697450120049579

Gauder, M., Houssard, C. \& Orsmond, D. (2014). Foreign Investment in Residential Real Estate. Reserve Bank of Australia. Bulletin, 11-18.

Görer Tamer, N., Erdoğanaras, F., Güzey, Ö. \& Yüksel, Ü. (2006). Effects of second home development by foreign retiremen tmigration in Turkey. 42 nd ISoCaRPCongress. http://www.isocarp.net/Data/case_studies /790.pdf 
Görer Tamer, N., Erdoğanaras, F., Yüksel, Ü. \& Güzey, Ö. (2010). Türkiye'de Yabancı Gerçek Kișilere Mülk Satıșının Niceliksel, Niteliksel Boyutları ve Mekansal Etkileri Üzerine Bir Değerlendirme. Memleket Siyaset Yönetim, 5(12), 120-141.

Guest, R. \& Rohde, N. (2017). The contribution of foreign real estate investment to housing price growth in Australian capital cities. ABACUS, 53(3), 304-318. https://doi.org/10.1111/abac.12110

Gustafson, P. (2008). Transnationalism in Retirement Migration: The Case of North European Retirees in Spain. Ethnic and Racial Studies, 31(3), 451-475. https://doi.org/10.1080/01419870701492000

Gündüz, E. (2003). Tatil Amaçlı Íkinci Konutların Fiziksel ve Sosyal Yapıya Etkileri Mahmutlar Örneği (Publication No. 134223) [Master's thesis, Selçuk Üniversitesi]. YÖK Tez Merkezi.

Hall, C.M. \& Müller, D.K. (2004). Tourism, mobility and second homes between elite landscape and common ground. Channel View Publications.

Huang, Y. \& Yi, C. (2011). Second home ownership in transitional urban China. Housing Studies, 26(3), 423-447. https://doi.org/10.1080/ 02673037.2011.542100

Karaaslan, Ş. \& Yalçıner Erçoşkun, Ö. (2005). İkinci konutların turizme kazandırılması: Antalya/Serik-Boğazkent örneği, Gazi Üniversitesi Bilimsel Araștırma Projesi, Proje No:06/2003-81, Gazi Üniversitesi Mühendislik Mimarlık Fakültesi, Şehir ve Bölge Planlama Programı.

Karakaya, E. ve Turan, A.H. (2006). Türkiye'de yabancı emekli göçü: Didim'in yeni sakinleri ve bölgeye ekonomik etkileri. Iktisat-IssletmeFinans, 21(246), 122-132. https://doi.org/110.3848/iif.2006.246.6732

Kaltenborn, B.P. \& Clout, H.D. (1998). The alternate home-motives of recreation home use. Norwegian Journal of Geography, 52(3), 121-134. https://doi.org/10.1080/00291959808552393

Keleş R. (2009). Kentleşme Politikası. İmge Yayınevi.

Kocatürk Özcan, F. (2006). Konut Alanı Yer Seçimi ve Hanehalkı Hareketliliğine Yönelik Bir İnceleme. Sosyal Bilimler Enstitüsü Dergisi, 21(2), 73-95,

Li, T. \& Fan, C.C. (2020). Occupancy, usage and spatial location of second homes in urban China. Cities, 96, 102414. https://doi.org/10.1016/j.cities.2019.102414

Lipkina, O. (2013) Motives for Russian Second Home Ownership in Finland. Scandinavian Journal of Hospitality and Tourism, 13(4), 299-316. https://doi.org/10.1080/15022250.2013.863039

Malczewski, J. (1999). GIS and Multicriteria Decisin Analysis. Wiley.

Malczewski, J. (2006). Ordered weighted averaging with fuzzy quantifiers: GIS-based multicriteria evaluation for land-use suitability analysis. International Journal Applied Earth Observation and Geoinformation, 8(4), 270-277. https://doi.org/10.1016/j.jag.200 6.01 .003

Manaugh, K. \& El-Geneidy, A.M. (2013). Does distance matter? Exploring the links among values, motivations, home location, and satisfaction in 
walking trips. Transportation Research Part A: Policy and Practice, 50, 198-208. https://doi.org/10.1016/j.tra.2013.01.044

Meyer, J. R. and Gomez- Ibanez L. K. (1981). Autos, Transit, and Cities. Harvard University Press.

Mizan, G. (1994). Turizm ve Íkinci Konut Gelişiminin Doğal Çevre Üzerindeki Etkilerinin İncelenmesi: Dilek Yarımadası ve Yakın Çevresi Örneği (Publication No. 39470) [Master's thesis, Ylldız Teknik Üniversitesi]. YÖK Tez Merkezi.

Müller, D. K. (2002). Reinventing the countryside: German second-home owners in Southern Sweden. Current issues in tourism 5(5), 426-446. https://doi.org/10.1080/13683500208667933

Müller, D. K. \& Roger, M. (2011). From Second Home to Primary Residence: Migration towards Recreational Properties in Sweden 19912005. Tijdschrift voor Economische en Sociale Geografie, 103(1), 53 - 68. https://doi.org/10.1111/j.1467-9663.2011.00674.x

Nepal, S.K. \& Jamal, T.B. (2011). Resort-induced changes in small mountain communities in British Columbia, Canada. Mountain Research and Development, 31(2), 89-101. https://doi.org/10.1659/MRDJOURNAL-D-10-00095.1

Nudral, F.Ö. (2007). The experiences of citizens in Didim, a coastal town in Turkey: a case study of lifestyle migration (Publication No. 217789) [Doctoral thesis, Middle East Technical University). YÖK Tez Merkezi.

Norris, M. \& Winston, N. (2010). Second-Home Owners: Escaping, Investing or Retiring?. Tourism Geographies, 12(4), 546-567. https://doi.org/10.1080/14616688.2010.516401

O'Reilley, K. (2001). The British on the Costa del Sol: transnational communities and local identities. Routledge.

Overvag, K. \& Berg, N.G. (2011). Second homes, rurality and contested space in Eastern Norway. Tourism Geographies: An International Journal of Tourism Space, Place and Environment, 13(3), 417-442. https://doi.org/10.1080/14616688.2011.570778

Paris, C., 2017. The super-rich and transnational housing markets: asians buying australian housing. In R. Forrest, S.Y. Koh \& B. Wissink (Eds.), Cities and the Super-Rich (pp.63-83). Springer.

Pereira, J.M.C. \& Duckstein, L. (1993). A multiple criteria decision-making approach to GIS based land suitability evaluation. International Journal of Geographical Information Systems, 7(5), 407-424. https://doi.org/10.1080/02693799308901971

Rovira Soto, M.T. \& Clave, S.A. (2017). Second homes and urban landscape patterns in Mediterranean coastal tourism destinations. Land Use Policy, 68, 117-132. https://doi.org/10.1016/j.landusepol.2017. 07.018

Rye, J. F. (2011). Conflicts and contestations. Rural populations' perspectives on the second homes phenomenon. Journal of Rural Studies, 27(3), 263-274. https://doi.org/10.1016/j.jrurstud.2011.03.00 5 Get rights and content

Saaty, T. (1980). The Analytic Hierarchy Process. McGraw-Hill. 
Location Site Selection Preferences of Construction Firms that Offer Second Homes to Foreign Investors: The Case of Trabzon

Silva, S., Alçada-Almeida, L. \& Dias, L. C. (2017). Multiobjective programming for sizing and locating biogas plants: a model and an application in a region of Portugal. Computers \& Operations Research, 83, 189-198. https://doi.org/10.1016/j.cor.2017.02.016

Stewart, S.I. \& Stynes, D.J. (1995). Toward a Dynamic Model of Complex Tourism Choices. Journal of Travel \& Tourism Marketing, 3(3), 69-88. https://doi.org/10.1300/J073v03n03_05

Südaş, İ. \& Mutluer, M. (2008). Ekonomik Etkileri Açısından Türkiye'nin Turizm Merkezlerine Yönelik Avrupalı Göçleri. Ege Coğrafya Dergisi, 17(1-2), 51-59.

Türk, E. (2018). Multi-criteria decision-making for greenways: the case of Trabzon, Turkey. Planning Practice \& Research, 33(3), 326-343. https://doi.org/10.1080/02697459.2017.1378864

Türk, E. \& Çelik, H.M. (2013). Impacts of planners' different viewpoints on optimum land-use allocation. European Planning Studies, 21(12), 19371957. https://doi.org/10.1080/09654313.2012.722967

Türk, E. \& Zwick, P.D. (2019). Optimization of land use decisions using binary integer programming: The case of Hillsborough County, Florida, USA. Journal of Environmental Management, 235, 240-249. https://doi.org/10.1016/j.jenvman.2019.01.031

Turkish Statistical Institute (2021). House sales numbers to foreigners by nationalities (2015-2020) [Data set]. https://data.tuik.gov.tr/B ulten/Index?p=Konut-Satis-Istatistikleri-Ocak-2021-37465

Turkish Statistical Institute (2021). House sales numbers to foreigners (2013-2020) [Data set]. https://data.tuik.gov.tr/Bulten/Index?p=KonutSatis-Istatistikleri-Ocak-2021-37465

Ünlü, C. (2018). Yabancıların İkinci Konut Arz-Talebinin Kentlere Etkileri: Trabzon Örneği (Publication No. 492438) [Master's thesis, Karadeniz Teknik Üniversitesi]. YÖK Tez Merkezi.

Ünlü Öztürk, C. \& Yılmaz Bayram, Z. (2021). Yabancı Coğrafyada Konut Talebinin Sosyal ve Ekonomik Etkileri: Trabzon Örneği. Coğrafya Dergisi, 42, 181-194. https://doi.org/10.26650/JGEOG2021-886312.

Voogd, H. (1983). Multicriteria Evaluation for Urban and Regional Planning. Pion Ltd.

Wokker, C. \& Swieringa, J. (2016). Foreign investment and residential property price growth Treasury Working Paper. Australian Government The Treasury. https://treasury.gov.au/sites/default/files/201903/TWP_FI_Residential_Property_Price_Growth.pdf

Yirik, S.. \& Baltacı, F. (2016). İkinci Konut Turizmi Kapsamında Antalya'ya Yerleşen Yabancıların Demografik Özelliklerinin ve Antalya'yı Tercih Etme Nedenlerinin Belirlenmesi. Akademik Araştırmalar Dergisi, 68, 137156.

Zoğal, V. \& Emekli, G. (2018). Urla'da (İzmir) ikinci konutların değerlendirilmesine yönelik nitel bir araştırma. Turizm Akademik Dergisi, 5(1), 189-204

Zucca, A., Sharifi, A.M. \& Fabbri, A.G. (2007). Application of spatial multicriteria analysis to site selection for a local park: a case study in Bergamo 
Province, Italy. Journal of Environmental Management, 88(4), 752-769. https://doi.org/10.1016/j.jenvman.2007.04.026

\section{Resume}

Ceren Ünlü Öztürk currently works at KTU, Department of Urban and Regional Planning, as a research assistant. She received her bachelor's degree in city and regional planning from Mimar Sinan Fine Arts University (2013) and master's degree from KTU (2018). She is also a PhD student at KTU, Urban and Regional Planning Program.

Ersin Türk received his bachelor's degree in city and regional planning from Dokuz Eylül University (1998), master's degree (2003), and PhD. degree (2009) in city planning from Izmir Institute of Technology. Currently works as an associate professor at Karadeniz Technical University, Department of Urban and Regional Planning. 